\title{
Diskursus Kurikulum Pendidikan Islam, Konsep dan Implementasinya
}

\author{
As'ad Samsul Arifin \\ Pascasarjana UIN Kiai Haji Ahmad Shiddiq Jember, Jawa Timur
}

Keywords:

Kurikulum, Pendidikan, Al-Qur'an, Hadits
Abstract: In education, the curriculum is the heart of an educational institution, which includes the planning, implementation and evaluation of the learning process. However, the curriculum that is developing in Indonesia is an adoption of various curriculum models and also frequently changes in curriculum. This of course makes various types of schools, both public schools and religion-based schools or madrasah, do not have curriculum principles that are in accordance with Islamic values. Therefore, this article has discussed the educational curriculum in the study of the Qur'an and Hadith in the ontology and epistemology aspects. In the ontology aspect, the curriculum itself has been discussed in detail from etymology to terminology. In the epistemological aspect we see how the Al-quran has taught us ways / teaching methods to students. And also discussed about the application of education during the Prophet's era and the application of the kriculum in the present so that it can be seen where its relevance is to the existing curriculum theory.

\begin{abstract}
Abstrak:
Dalam pendidikan, kurikulum merupakan jantung dari suatu lembaga pendidikan, yang meliputi perencanaan, pelaksanaan dan evaluasi proses pembelajaran. Namun, kurikulum yang berkembang di Indonesia merupakan adopsi dari berbagai model kurikulum dan juga sering terjadi perubahan kurikulum. Hal ini tentunya membuat berbagai jenis sekolah, baik sekolah umum maupun sekolah atau madrasah berbasis agama, tidak memiliki prinsip-prinsip kurikulum yang sesuai dengan nilai-nilai Islam. Oleh karena itu, artikel ini membahas kurikulum pendidikan dalam kajian Al-Qur'an dan Hadits dalam aspek ontologi dan epistemologi. Dalam aspek ontologi, kurikulum sendiri telah dibahas secara mendetail mulai dari etimologi hingga terminologi. Dalam aspek epistemologis kita melihat bagaimana Al-Qur'an telah mengajarkan tentang cara/metode pembelajaran kepada siswa. Dan juga dibahas tentang penerapan pendidikan pada masa Nabi dan penerapan kurikulum pada masa sekarang sehingga dapat diketahui relevansinya dengan teori kurikulum yang ada.
\end{abstract}




\section{PENDAHULUAN}

Kurikulum merupakan salah satu elemen penting dari sistem pendidikan sebab digunakan untuk merencakan, melaksanakan, dan mengevaluasi hasil yang sudah dicapai dalam proses pembelajaran, dapat meliputi aspek material, non material hingga kegiatan yang perlu dialami peserta didik selama mengikuti pendidikan.

Di Indonesia, kurikulum pendidikan telah mengalami pergantian hampir setiap sepuluh tahun sekali, meskipun di akhir-akhir tahun belakangan terjadi beberapa pergantian yang menimbulkan pro dan kontra. Kurikulum Indonesia tersebut, yaitu Kurikulum 1974, Kurikulum 1984, Kurikulum 1994, Kurikulum 2004 (transisi KTSP), Kurikulum 2006, dan yang terakhir Kurikulum 2013.

Kurikulum pendidikan yang bisa disusun dan dilaksanakan sesuai dengan perencanaan yang matang, kreatif dan inovatif lebih cenderung dianggap berhasil dengan baik dan disukai oleh masyarakat. Sudah menjadi fenomena umum bahwa suatu lembaga pendidikan akan tampak sukses dan menjadi sekolah/ madrasah favorit jika bisa merencanakan dan menjalankan program-program pen-didikan yang kreatif dan inovatif dengan baik, sesuai dengan tuntutan jaman yang penuh dengan tantangan-tantangan global.

Selain itu, bagi lembaga pendidikan Islam, tidak keliru bila membaca kembali ayat-ayat Al Qur'an dan Hadits Nabi untuk dijadikan dasar dalam menginterpretasikan materi pendidikan ke dalam kurikulum pendidikan yang inovatif. Hal itu sangat dimungkinkan karena kedua sumber Islam tersebut merupakan tuntunan hidup umat Islam dalam segala aktifitasnya, baik hubungannya dengan Tuhan, manusia dan alam semesta.
Kajian tentang kurikulum dalam pandangan Al-Qu'an dan Al-Hadits telah dibahas oleh beberapa peneliti maupun penulis, di antaranya Umi Mahmudah menulis Kurikulum Pendidikan dalam Kajian Al-Qur'an dan Hadits Tematik. Penelitian Umi fokus pada Kajian Tematik Al-Qur'an Hadits, dalam aspek ontologi, epistemolgi dan aksiologis. Secara ontologi meliputi pengertian kurikulum, sedangkan secara epistemologi meliputi metode mengajar, sementara secara ontologi meliputi penerapan kurikulum pendidikan pada masa Rasulullah dan implikasinya dalam praktek pendidikan Islam saat ini.

Penelitian lain oleh Farida Jaya yang membahas hadis-hadis tentang kurikulum pendidikan Islam, sementara Moh. Aman Menyusun pengertian dan perspektif kurikulum pendidika Islam dalam Al-Qur'an berdasarkan pendapat para ulama, selebihnya lebih para peneliti lain banyak membahas tentang konsep pendidikan secara umum dalam perspektif Al-Qur'an.

Berbeda dengan studi yang telah disebutkan di atas artikel ini bertujuan untuk membahas tentang konsep kerikulum pendididkan dalam prespektif Al-Quran dan Al-Hadis (disingkat Qurdis), relevansi/perbandingan dengan teori kurikulum secara umum, dan aplikasinya dalam pendidikan Islam.

\section{KAJIAN TEORI Pengertian Kurikulum}

Berbicara kurikulum, tentu menjadi dilema bagi seorang calon pendidik, dari sekian banyak pembahasan, hampir tidak menemukan metode yang sesuai dan pas untuk diterapkan dilingkungan sekolah. Dalam praktek atau pengaplikasiannya kurikulum 
pendidikan selalu terdapat kekurangan meskipun telah direvisi beberapa kali. Hal ini bisa dikatakan, kurikulum yang sebenarnya belum benar-benar selesai dan relevan dengan perkembangan zaman, dalam artian kurikulum harus selalu bisa beradaptasi dengan situasi dan kondisi baru, sehingga revisi kurikulum menjadi aktivitas yang tidak dapat dihindari.

Secara etimologi kurikulum berasal dari kata Bahasa Yunani 'curere' yang berarti jarak yang harus ditempuh oleh seorang pelari dari start sampai finish. ${ }^{1}$ Sedangkan dalam Bahasa Arab kurikulum dikenal dengan istilah al- manhaj yang berarti jalan terang yang dilalui manusia dalam kehidupannya. ${ }^{2}$ Sedangkan dalam buku Oxford Advanced Learner's Dictionary of Current English dikatakan bahwa "curriculum is the subjects included in a course of study or taught at a particular school, college, etc. ${ }^{3}$ Ini berarti bahwa kurikulum adalah mata pelajaran yang dimasukkan dalam suatu rangkaian pembelajaran atau mata pelajaran yang diajarkan pada suatu sekolah, lembaga pendidikan, dan sebagainya.

Secara istilah, kurikulum dimaknai secara beragam, misalnya dimengerti sebagai suatu rencana ideal tentang pengalaman apa yang mesti dialami oleh peserta didi di sekolah. Kurikulum juga dianggap segala materi yang harus dipelajari, berisi bahan atau kajian yang bersumber dari buku atau apapun instrumen pengetahuan yang diterapkan di

\footnotetext{
1 Sudjana (2002) dalam Heri Gunawan, Kurikulum dan Pembelajaran Pendidikan Agama Islam, (Bandung: Alfabeta, 2012), 1

2 Al Basyir dan Said (1995) dalam Heri Gunawan, Kurikulum dan Pembelajaran Pendidikan Agama Islam, 1

3 A.S. Hornby, Oxford Advanced Learner's Dictionary of Current English, (USA: Oxford University Press, 1995), 287
}

sekolah/lembaga pendidikan. ${ }^{4}$ Kurikulum juga diartikan sebagai suatu rencana kegiatan belajar yang terdiri dari rumusan tujuan, bahan ajar, kegiatan belajar dan mengajar, jadwal, serta evaluasi pembelajaran di sekolah. Dengan demikian kurikulum memiliki arti yang sangat luas dibanding materi pelajaran itu sendiri.

Berdasarkan UU No. 20 tahun 2003 dijelaskan bahwa kurikulum adalah seperangkat rencana dan pengaturan mengenai tujuan, isi, dan bahan pelajaran serta cara yang digunakan sebagai pedoman penyelenggaraan kegiatan pembelajaran untuk mencapai tujuan pendidikan tertentu. Dalam pengertian tersebut dimengerti bahwa kurikulum merupakan instrumen pendidikan yang menjadi pedoman dalam rangka mencapai tujuan pendidikan yang diinginkan oleh masing-masing lembaga pendidikan.

Menurut Muhammad Muzamil alBasyir kurikulum adalah "Jami'u Maa Tuqarriruhu al-Madrasati wa Taraahu Dharuriyan li al-Talamidz, Ba'da Nadhri an-Hajatihi wa Qadratihi wa Muyulihi wa Baidan an al-Washti alIjtima'l wal Hayati al-Ijtimaiyati allati Tandhoruhu fi al-Mustaqbal", yang artinya bahwa kurikulum adalah kumpulan mata pelajaran yang harus disampaikan guru atau dipelajari oleh siswa. ${ }^{5}$ Kurikulum berdasarkan pengertian di atas masih dianggap sebagai cara pandang lama karena fokus dari kurikulum sendiri masih pada mata pelajaran yang wajib diselesaikan oleh siswa untuk

\footnotetext{
4 Mursalim dan Hatta, Inovasi Pengembangan Kurikulum PAI di Sekolah Menengah Pertama Raudatut Tholabah Berbasis Pesantren, (Jember: Fakultas Tarbiyah dan Ilmu Keguruan: IAIN Jember, 2020), 3

5 Muhammad Muzamil al-Basyir (1995) dalam Heri Gunawan, Kurikulum dan Pembelajaran Pendidikan Agama Islam, 1
} 
mencapai hasil akhir yaitu lulus dari suatu sekolah.

Berbagai pendapat yang dijelaskan diatas dapat kita ketahui bersama bahwasanya pengertian kurikulum yang sesungguhnya ialah suatu capaian pembelajaran. Kurikulum juga diartikan sebagai pedoman seorang guru dalam hal mendidik murid selama disekolah dengan tujuan untuk mempermudah belajar mengajar kepada siswa. Sehingga adanya kurikulum ini juga berpengaruh terhadap peserta didik dan juga guru.

Seiring dengan perkembangan teori dan praktik dalam dunia pendidikan, juga meningkatnya sarana dan prasarana di lembaga pendidikan, pengertian kurikulum pun semakin meluas cakupannya, Hilda Taba mengatakan bahwa "A curriculum is a plan for learning, therefore, what is known about the learning process and the development of the individual has bearing on the shaping of a curriculum". ${ }^{6}$ Dalam pengertian tersebut kurikulum merupakan seperangkat rencana pembelajaran yang meliputi input, proses dan output pembelajaran, baik berupa pengalaman kognitif, afektif maupun psikomotorik siswa di dalam dan luar kelas. Dengan demikian kurikulum tidak bisa dimaknai sebagai suatu materi tertulis saja, namun lebih dari itu kurikulum meliputi segala aktivitas pendidikan. ${ }^{7}$

Menurut Nasution kurikulum dipandang sebagai suatu rencana yang dibuat untuk melaksanakan proses pembelajaran di bawah petunjuk dan tanggungjawab sekolah beserta dewan guru. ${ }^{8}$ Nasution membagi kurikulum

6 Hilda Taba (1962) dalam Wina Sanjaya, Pembelajaran dalam Implementasi Kurikulum Berbasis Kompetensi, (Jakarta: Kencana Prenada Media Group, 2006), 5 menjadi dua, yaitu: kurikulum formal dan tak formal. Kurikulum formal meliputi: (1) Tujuan Pelajaran umum, dan spesifik; (2) Bahan pelajaran yang tersusun sistematis; (3) Strategi belajar-mengajar serta kegiatankegiatannya; dan (4) Sistem evaluasi untuk mengetahui hingga mana tujuan tercapai.

Sedangkan kurikulum tak formal terdiri dari kegiatan co-curriculum dan extra-curriculum. Kegiatan cocurriculum adalah kegiatan yang mendukung langsung kegiatan formal atau Intra-curriculum, misalnya pemberian tugas yang berkaitan dengan bahan ajar saat itu sehingga bisa membantu untuk penilaian siswa. Sedangkan kegiatan extra-curriculum meliputi kegiatan- kegiatan yang berfungsi utamanya untuk menyalurkan/mengembangkan kemampuan siswa sesuai dengan minat dan bakatnya, memperluas pengetahuan, belajar bersosilisasi, menambah keterampilan, mengisi waktu luang, dan lain sebagainya, bisa dilaksanakan di sekolah ataupun kadang- kadang bisa di luar sekolah. Kegiatan ini biasanya dilaksanakan di luar jam pembelajaran. Ada lagi yang disebut dengan hidden curriculum, yaitu kurikulum tersembunyi, dimana kurikulum ini berupa aturan atau kebijakan yang tidak tertulis, tetapi dilaksanakan di sekolah/madrasah, misalnya kebiasaan bersalaman ketika bertemu dengan guru.

Dalam kajian Pendidikan Islam perencanaan kurikulum diupayakan sesuai dengan nilai-nilai Islam, seperti materi atau aktivitas apa yang layak untuk dipelajari, terutama tujuan apa yang hendak dicapai dalam proses

\footnotetext{
7 Wina Sanjaya, Pembelajaran dalam Implementasi Kurikulum Berbasis Kompetensi, (Jakarta: Kencana Prenada Media Group, 2006), 4-5

8 Nasution, Kurikulum \& Pengajaran, (Jakarta: PT Bumi Aksara, 2012), 5
} 
pendidikan. Dalam Shahih Muslim ${ }^{9}$ terdapat hadits yang relevan dengan pembahasan perumusan tujuan pendidikan, berikut disabdakan oleh Rasulullah SAW.:

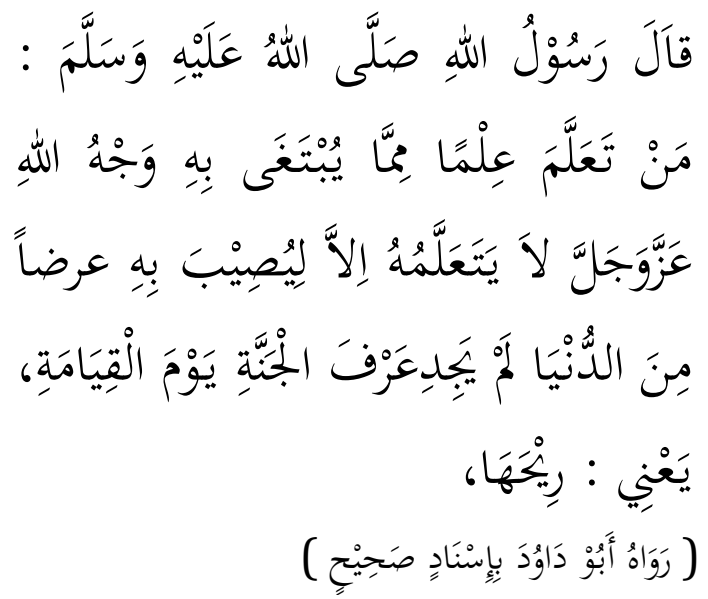

Dari Abu Hurairah ra. Ia berkata Rasulullah SAW bersabda : "Barang siapa yang mempelajari ilmu pengetahuan yang semestinya bertujuan untuk mencari ridho Allah 'Azza wa Jalla. Kemudian ia mempelajarinya dengan tujuan hanya untuk mendapatkan kedudukan / kekayaan duniawi, maka ia tidak akan mendapatkan baunya syurga kelak pada hari kiamat." (HR. Abu Daud).

Hadits tersebut menjelaskan tentang bagaimana peran dan tujuan seorang yang mencari ilmu. Pada hakikatnya mencari ilmu bukan untuk kesenangan semata, melainkan karena mengharap ridho Allah. Seseorang yang memiliki tujuan selain itu diyakini sangat sulit untuk mendapatkan ilmu yang berkah, yaitu ilmu yang mendatangkan manfaat baik di dunia maupun di akhirat kelak.

Secara moral, umat Islam dibiasakan untuk Dalam implementasinya telah jelas tergambarkan bahwa dalam kehidupan umat Islam dianjurkan untuk selalu memulai sesuatu dari kanan. Dalam artian manusia dianjurkan untuk selalu berbuat kebaikan. Segala sesuatu mulai dari berwudhu', makan, minum, hingga memakai pakaian disunnahkan mengutamakan dan memakai anggota tubuh sebelah kanan terlebih dahulu. Maka kehidupan telah menggambarkan bagaimana kebaikan merupakan suatu keharusan yang kita lakukan. Kebaikan yang sesungguhnya adalah kebaikan dengan selalu menempatkan diri di jalan Allah SWT.

Dari uraian di Atas, hubungan dengan kurikulum yakni merupakan penjelasan Rasulullah atas sikap yang menunjukkan bahwa kehidupan kita merupakan sebuah gambaran dari kurikulum atau perjalanan yang harus ditempuh. Seorang mencari ilmu akan menjadi sia-sia ketika kedudukan menjadi tujuan awal dari output pembelajaran. Sebuah gunung adalah rumah para syuhada dimana tidak mungkin kita bisa meraihnya itu adalah para pejuang jihad terdahulu. Selanjutnya tiang sebagai pegangan hidup yakni AL-Qur'an dan Al-Hadist yang harus menjadi pegangan hidup yang harus kita jalani.

Adapun hubungan dengan kurikulum pendidikan, yakni digambarkan bagaimana kurikulum seharusnya, terutama kurikulum dalam sebuah proses mendidik anak. Dengan ini dijelaskan dalam Al-Qur'an surat Al-Luqman ayat 12 , yang berbunyi:
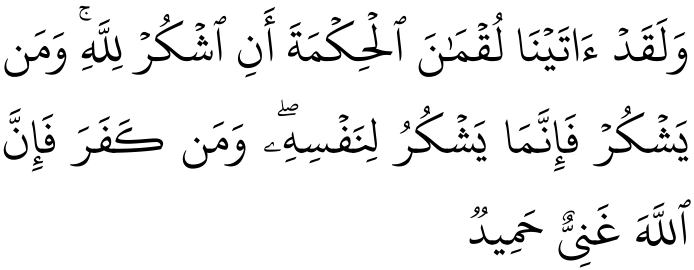
"Dan sesungguhnya telah Kami berikan hikmat kepada Luqman, yaitu: "Bersyukurlah kepada Allah. Dan barangsiapa yang bersyukur (kepada Allah), maka sesungguhnya ia bersyukur untuk dirinya sendiri; dan barangsiapa yang tidak bersyukur, maka sesungguhnya Allah Maha Kaya lagi Maha Terpuji".

Menurut M. Quraish Syihab ${ }^{10}$ bahwa para ulama' mengajukan aneka keterangan makna hikmah. Antara Lain A-Baihaqi menulis bahwa hikmah berarti "Mengetahui yang paling utama dari segala sesuatu baik pengetahuan maupun perbuatan. Ia adalah ilmu amaliah dan ilmu ilmiah. Ia adalah ilmu yang didukung oleh amal dan amal yang tepat didukung oleh ilmu". Hikmah berasal dari kata Hakamah yang berarti kendali, yaitu sesuatau jika dimanfaatkan akan menghalangi terjadinya kerugian atau kesulitan yang lebih besar sehingga akan mendatangkan kemaslahatan dan kemudahan yang lebih besar. Kadang kendali juga digunakan untuk menghalangi hewan atau kendaraan menjadi liar. Bentuk perbuatan hikmah adalah ketika memilih perbuatan yang terbaik dan sesuai. Bahkan memilih yang terbaik dan sesuai dengan hal yang buruk pun, dinamakan Hikmah dan pelakunya adalah Hakim (Bijaksana).

Hikmah dapat membentuk orang percaya diri, hal tersebut senada dengan pengertian kurikulum itu sendiri yakni "Suatu rencana yang memberi pedoman atau pegangan dalam proses kegiatan belajarmengajar". Agar tidak melenceng dari substansi ilmu, maka tugas seorang guru adalah membimbing, mengajar, dan melatih peserta didik dengan profesional sehingga tujuan pendidikan sendiri bisa tercapai dengan baik. Maka dalam pelaksanaan tugasnya, seorang guru harus berpedoman pada kurikulum. Kurikulum merupakan seperangkat rencana dan pengaturan mengenai isi dan bahan pengajaran, serta cara yang digunakan dalam menyelenggarakan belajar mengajar (UU No. 2 Tahun 1989). Dan ini bertujuan sebagai arah, pedoman, atau sebagai rambu-rambu dalam pelaksanaan proses pembelajaran.

Dalam Undang-Undang Nomor 20 tentang Sistem Pendidikan Nasional tahun 2003, dijelaskan bahwa kurikulum adalah seperangkat rencana dan pengaturan mengenai tujuan, isi, dan bahan pelajaran serta cara yang digunakan sebagai pedoman penyelenggaraan kegiatan pembelajaran untuk mencapai tujuan pendidikan tertentu.

Kurikulum merupakan bagian yang tidak boleh terpisahkan antara pendidikan dan pembelajaran, maka kurikulum merupakan syarat yang harus ada dalam sekolah. Kurikulum mengarahkan segala bentuk aktivita pendidikan demi tercapainya tujuantujuan pendidikan, sehinggan mempunyai kedudukan sentral dalam seluruh proses pendidikan.

\section{METODE}

Penelitian ini menggunakan pendekatan penelitian yang berusaha mendeskripsikan suatu gejala secara kulaitatif terhadap konsep kurikulum dalam prespektif Qur'an dan Hadist. Sedangkan teknik pengumpulan data

\footnotetext{
${ }^{10}$ M Quraish Syihab, Tafsir Al-Mishbah: Pesan, Kesan dan Keserasisan Al-Qur'an (Volume 11), (Jakarta: Lentera Hati, 2002), 120
} 
menggunakan kepustakaan dengan data skunder yang bersumber dari jurnal, buku, skripsi, thesis, dan studi pustaka lain yang mendukung dalam penelitian ini.

\section{HASIL DAN PEMBAHASAN}

\section{Epistimologi Kurikulum Pendidikan}

Hal yang paling membedakan antara manusia dengan makhluk lainnya adalah akal, manusia dikaruniai pikiran dan akal yang lengkap untuk berfikir. Selain itu, manusia juga makhluk yang bisa berfikir dan memiliki perasaan, sehingga manusia cenderung untuk selalu berubah. Karena pada hakekatnya manusia merupakan makhluk ciptaan Allah yang memiliki derajat paling tinggi dari makhluk Allah yang lainnya.

Hampir sama halnya dengan kurikulum juga bertujuan untuk memperbaiki kualitas pendidikan. Begitu juga dengan adanya perubahan Kurikulum 201311 mempunyai landasan filosofis yaitu:

1. Pendidikan berakar pada budaya bangsa, kehidupan masa kini dan membangun landasan kehidupan masa depan.

2. Pendidikan adalah proses pewarisan dan pengembang budaya.

3. Pendidikan memberikan dasar bagi untuk peserta didik berpartisipasi dalam membangun kehidupan masa kini.

4. Pendidikan mengembangkan berbagai potensi yang dimiliki peserta didik

5. Pendidikan adalah proses pengembangan jatidiri peserta didik.
6. Pendidikan menempatkan peserta didik sebagai subjek yang belajar

Adanya kurikulum tidak lepas berawal dari kekurangan ketika seorang guru menerapkan pembelajarannya. Sebuah temuan dan juga pemikiran seorang guru menjadi ppolemik untuk menciptakan suatu inovasi baru supaya memberikan kreatifitas melalui sistem pembelajarannya.

Kajian kurikulum tidak lepas atau berangkat dari seorang guru yang polos saja, namun adanya kurikulum ini karena memang faktor kebutuhan. Jika kita kaji dalam konteks islam, maka kurikulum sebenarnya sudah ada sejak dahulu kala. Mulai dari sebelum nabi muhammad sudah ada yang namanya pendidikan karakter, pendidikan sikap, pendidikan mental bahkan fisik sekalipun sudah ada pada masa rosulullah.

Namun, hal demikian tidak menjadi pedoman khusus dalam pendidikan. Hanya saja sebagian telah dicontohkan oleh para nabi-nabi terdahulu. Perintahnya pun cukup luas dalam Al-Qur'an. Banyak disebutkan bagaimana cara mendidik seorang anak, kewajiban mencari ilmu, dan juga pentingnya ilmu dalam kehidupan.

Capaian dari kurikulum bahkan hampir sama semuanya. Menginginkan output dari pengaplikasinnya menginginkan peserta didik lebih aktidf, kreatif, inovatif, bertaqwa kepada Alah SWT. Maka dari itu tak kalah penting secara 
umum tentang penerapan kurikulum, terhadap lingkungan pendidikan sekolah khususnya.

Sedangkan, sebagai landasan Islam tentang pentingnya kurikulum, dimana dalam kurikulum selalu ada perubahan dari tahun ke tahun karena menginginkan adanya perubahanperubahan, tercantum dalam Al Qur'an Surat Ar Ra'd, ayat 11 beserta tafsirannya ${ }^{12}$ :

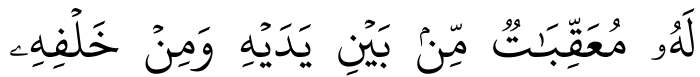

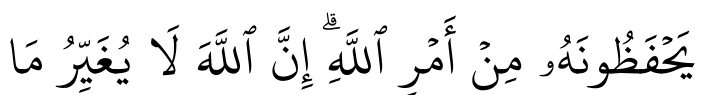

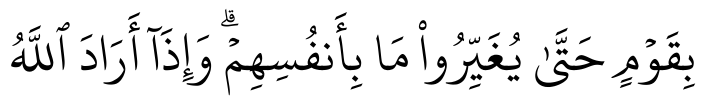

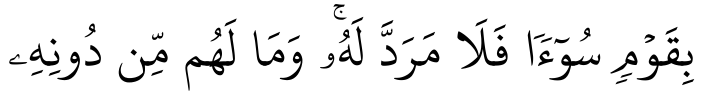

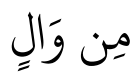

"Bagi manusia ada malaikatmalaikat yang selalu mengikutinya bergiliran, di muka dan di belakangnya, mereka menjaganya atas perintah Allah. Sesungguhnya Allah tidak merubah keadaan sesuatu kaum sehingga mereka merubah keadaan yang ada pada diri mereka sendiri. Dan apabila Allah menghendaki keburukan terhadap sesuatu kaum, maka tak ada yang dapat menolaknya; dan sekali-kali tak ada pelindung bagi mereka selain Dia."

Dapat disimpulkan bahwa ayat ini menjelaskan diwaktu apapun dan dimanapun manusia akan selalu di jaga oleh malaikat secara bergiliran. Mereka akan selalu mencatat segala bentuk amalan dan perbuatan manusia

12 M. Quraish Sihab, Tafsir Al-Mishbah: Pesan, Kesan dan Keserasian Al-Qur'an, (Volume 6), (Jakarta: Lentera Hati, 2002), 564-565 baik itu jelek maupun amalan yang baik semasa hidupnya.

Selanjutnya Allah tidak akan mengubah suatu nasib tanpa adanya usaha dari manusia itu sendiri. Maka yang dimaksud adalah usaha dan kerja keras manusia itu sendirilah yang akan merubah nasib manusia dari positif maupun negatif, begitu pula sebaliknya. Dari sini kita tidak boleh hanya bermalasan mengharapkan pertolongan Alloh Swt, tanpa berikhtiar terlebih dahulu. Sekecil apapun usaha kita, pasti Alloh akan membalasnya. Akan tetapi, jika Alloh menghendaki keburukan suatu bangsa, maka itulah kehendakNya berdasarkan sunnatullah dan tidak ada satupun yang bisa menolaknya dan pastilah sunnatullah menimpanya, maka tidak ada pelindung baginya selain Allah.

Kaitannya dengan kurikulum, meskipun sejak dulu kurikulum yang berada di indonesia ini selalu berubahubah karena tidak lain dari hasil komponen kurikulum yang ke empat yakni komponen evaluasi. Jadi sebenarnya adanya peubahan dalam kurikulum pendidikan islam yaitu ialah dikarenakan terdapat ketidak sesuaian kettika di aplikasikan dalam kelas. Sehingga hal ini membutuhkan pembaharuan supaya bisa beradapatasi dan bisa menyesuaikan dengan kodisi yang terjadi.

\section{Komponen- Komponen Kurikulum}

Dalam Lampiran Permendiknas Nomor 61 tahn 2014, komponenkomponen kurikulum KTSP 2013, ada 3 dokumen, yaitu Buku I KTSP, Buku II KTSP dan Buku III KTSP ${ }^{13}$. Buku I atau disebut juga Dokumen I berisi paling sedikit ada visi, misi, tujuan,

13 Heri Gunawan, Kurikulum dan Pembelajaran Pendidikan Agama Islam, (Bandung: Alfabeta, 2012), 9 
muatan, pengaturan beban belajar, dan kalender pendidikan. Buku II berisi silabus yang sudah disusun oleh pemerintah. Sedangkan Buku III berisi Rencana Pelaksanaan Pembelajaran yang disusun sendiri oleh para pendidik.

Adapun komponen-komponen yang membentuk sistem kurikulum menurut Muhammad Muzamil alBasyir dalam Heri Gunawan adalah: (1) Tujuan Kurikulum; (2) Materi; (3) Metode; dan (4) Evaluasi ${ }^{14}$

\section{Komponen Tujuan Kurikulum}

Berhubungan dengan arah atau hasil yang diharapkan. Dalam skala makro, rumusan tujuan kurikulum erat kaitannya dengan filsafat atau sistem nilai yang dianut masyarakat. Dalam skala mikro, tujuan kurikulum berhubungan dengan misi dan visi sekolah serta tujuan yang lebih sempit, seperti tujuan setiap mata pelajaran dan tujuan proses pembelajaran. Tujuan kurikulum terdiri dari tujuan kognitif, psikomotorik dan afektif. Dimana tujuan kognitif terfokus kepada konstruksi dalam proses perfikir prsrta didik, termasuk dalam mengingat, memecahkan masalah, dan kemampuan untuk mengambil keputusan. Selanjutnya tujuan psikomotorik yang memfokuskan kepada gerakan dan koordinasi jasmani, ketrampilan motorik dan kemampuan fisik seseorang. Ketrampilan ini akan berkembang jika sering di praktekkan. Kemaudian yang terakhir adalah tujuan afektif dimana lebih menekankan pada ranah afeksi dimana adalah segala sesuatu yang berkaitan dengan jiwa rohasi peserta didik seperti emosi, penghargaan, nilai, semangat, dan sikap.

Ketiga aspek ini sangatlah berperan bagi perkembangan peserta didik karena aspek ini merupakan ukuran keberhasilan dalam suatu pendidikan. Dalam metode pendidikan lama aspek ukur pencapaian materi pembelajaran hanya terfokus pada hasil pembelajaran saja dan hanya pada aspek kognitif saja tanpa memperhatikan aspek yang lain. Dengan ini maka kerap sekali hasil dari pembelajaran tidak efekti.

Dengan adanya tiga tujuan yang saling berkaitan ini dirasa cukup efektif karena untuk mencapai suatu pengetahuan teretentu, yang diperlukan justru sebuah proses dan juga pengertian tentang konsep yang akan dicapai. Maka ketiga tujuan kurikulum ini menjadi tombak utama keberhasilan dalam penyampaian materi pembelajaran.

Diharapkan dalam kurikulum juga bisa mencakup ketiga hal tersebut. Pada hakekatnya, tujuan kurikulum ada tiga macam, yaitu Tujuan Nasional, Tujuan Institusional dan Tujuan Kurikuler. Tujuan Nasional tentu saja tujuan yang tercantum dalam UndangUndang Sisdiknas. Tujuan Institusional sesuai dengan tujuan lembaga pendidikan sebagai penyelenggara pendidikan. Sedangkan Tujuan Kurikuler adalah tujuan yang akan dicapai pada setiap bidang studi yang diajarkan.

\section{Komponen Materi}

Materi kurikulum merupakan komponen yang berhubungan dengan pengalaman belajar yang harus dimiliki siswa yang berisikan semua aspek baik yang berhubungan

\footnotetext{
14 Sudjana (2002) dalam Heri Gunawan, Kurikulum dan Pembelajaran Pendidikan Agama Islam, (Bandung: Alfabeta, 2012), 13
} 
dengan pengetahuan atau materi pelajaran. Semua itu diarahkan untuk mencapai tujuan yang ditentukan. Menurut Sudjana dalam Heri Gunawan mengatakan bahwa isi kurikulum adalah penentu berhasilnya suatu tujuan. ${ }^{15}$ Maka, isi kurikulum harus: (1) sesuai, tepat dan bermakna bagi perkembangan peserta didik; (2) mencerminkan kenyataan sosial, artinya sesuai dengan tuntutan hidup nyata masyarakat; (3) dapat mencapai tujuan yang komprehensif, artinya mengandung aspek sosial, moral dan sosial secara seimbang; mengandung pengetahuan ilmiah yang tahan uji, artinya tidak lekang oleh waktu; (5) mengandung bahan pelajaran yang jelas; (6) dapat menunjang tercapainya tujuan pendidikan.

Secara umum, materi kurikulum dalam pembelajaran sudah tercantum dalam Kompetensi Inti dan Kompetensi Dasar yang tercantum dalam Permendiknas Nomor 57, 58, 59 tahun 2014. Akan tetapi, jika kita mau melihat di dalam Al-Qur'an hampir semua ilmu yang ada di dunia sudah tercantum di dalamnya. Contoh beberapa ayat, antara lain ${ }^{16}$ :

\begin{tabular}{|l|l|l|}
\hline NO & $\begin{array}{l}\text { AYAT AL- } \\
\text { QUR'AN }\end{array}$ & ILMU UMUM \\
\hline 1 & An Najm ayat 32 & $\begin{array}{l}\text { Indera manusia, } \\
\text { kekosongan tubuh } \\
\text { dan } \\
\text { atom. }\end{array}$ \\
\hline 2 & $\begin{array}{l}\text { Al-Jatsiah ayat } \\
3-5\end{array}$ & $\begin{array}{l}\text { Perkembangbiakan } \\
\text { hewan, pergantian } \\
\text { siang dan malam, } \\
\text { turunnya rizki, } \\
\text { tanah } \\
\text { gersang, angin }\end{array}$ \\
\hline
\end{tabular}

15 Abdurrahman Umairah, Metode Al-Qur'an Dalam Pendidikan, Alih Bahasa: Abdul Hadi Basulthanah, (Surabaya: Mutiara Ilmu, 2000), 30-65

\begin{tabular}{|c|c|c|}
\hline 3 & Al-Anfal ayat 22 & Orang buta dan tuli \\
\hline 4 & $\begin{array}{l}\text { Al-Baqarah ayat } \\
170\end{array}$ & $\begin{array}{l}\text { Qaidah-qaidah atau } \\
\text { turan-aturan } \\
\text { Manusia }\end{array}$ \\
\hline 5 & $\begin{array}{l}\text { Fushilat 37, } \\
\text { al- An'am 74, } \\
\text { Asy- Syu'ara 71- } \\
81\end{array}$ & Ke-Tauhid-an \\
\hline 6 & $\begin{array}{l}\text { Fushilat 53, } \\
\text { Ath- } \\
\text { Thariq 5-8 }\end{array}$ & $\begin{array}{l}\text { Mengenal diri } \\
\text { sendiri (anggota } \\
\text { badan, } \\
\text { jantung, ginjal, } \\
\text { tulang rusuk, dll) }\end{array}$ \\
\hline 7 & $\begin{array}{l}\text { Al-mu'minun } \\
12-14\end{array}$ & Terjadinya manusia \\
\hline 8 & Al-Anbiya' 30 & $\begin{array}{l}\text { Lautan, sungai, } \\
\text { penguapan, hujan }\end{array}$ \\
\hline 9 & $\begin{array}{l}\text { Al-A'raf 171, Al- } \\
\text { Hijr 82-83, } \\
\text { Shaad 18, } \\
\text { An-Naba'6-7, } \\
\text { An- Nahl 81 }\end{array}$ & $\begin{array}{l}\text { Gunung-gunung, } \\
\text { rumah-rumah }\end{array}$ \\
\hline & Dll. & Dll. \\
\hline
\end{tabular}

Alangkah baiknya jika dalam proses pembelajaran kita juga mencantumkan ajaran-ajaran islam kepada peserta didik, seperti yang ada dalam al-hadist, Rasulullah bersabda yang artinya:

Dari Ibnu 'Umar, beliau berkata bahwa Rasulullah SAW pernah bersabda: "Ajari anak-anak lelakimu berkuda, berenang dan memanah, dan ajari menggunakan alat pemintal untuk wanita" (HR. Al- Baihaqi)

Alasan rasulullah menyuruh para orang tua untuk mengajarkan ketrampilan pada anak-anaknya karena. Bagi masyarakat padang pasir menunggang kuda dan unta serta

16 Umairah, Metode Al-Qur'an, 30-65 
memanah merupakan kebiasaan keseharian masyarakat arab. Berbeda dengan berenang, hal ini memicu keheranan padahal orang arab tidak terlalu suka dengan air. Kolam renang adalah hal yang sulit untuk ditemukan di padang pasir.

Adapun manfaat dari ketiga kegiatan olah raga yang telah disebutkan dalam hadist, diantaranya:

\section{a. Berkuda}

Secara fisik kuda tentu lebih kuat dari penunggangnya, namun sang oenunggang harusmengusai kuda tersebut agar dia bisa sampai ke tujuannya. Memnag sering kali kita harus memimpin seseorang yang lebih pintar, lebih kuat dan lebih banyak memiliki kelebihan. Berkuda melambnagkan simbol keberainan dan dan pengendalian sehingga dengan berkuda maka akan tibul sebuah simbol karakter. Dengan olah raga ini maka akan melatih jiwa kepemimpinan anak. Selain itu jiwa pemeberani, ketangkasan, menghilangkan rasa takut dan kepercayaan diri juga akan terbangun.

\section{b. Berenang}

Berenang dalam keutamaannya adalah melatih untuk mengatur pernapasan. Dimana fungsi nafas adalah untuk memasukan atau menghirup oksigen dari alam ke dalam tubuh kita melalui paru-paru. Oksigen yg kita hirup masuk ke paruparu, lalu aliran darah dari jantung masuk ke paru-paru. Fungsi paruparu adalah menukar oksigen dari udara dengan karbon dioksida dari darah. Prosesnya disebut "pernapasan eksternal" atau bernapas. Metabolisme tubuh di dalam organ dalam sangat menguras tenaga, sehingga hal ini sangat mengurangi energi tubuh. Pengaturan nafas yang baik sangat dibutuhkan.

Mahir

berenang/mengatur nafas akan kuat pernapasannya, dan ini amat besar pengaruhnya bagi kecerdasan ketika asupan oksigen ke otak itu terdistribusi dengan cukup dan Kondisi yg Prima.

Dengan pengaturan nafas maka persediaan oksigen akan cukup, teratur dan terkendali. Karena setiap aktifitas tubuh semakin berat maka oksigen yang dibutuhkanpun lebih banyak, ini kita bisa lihat dalam kondisi normal ditandai dengan nafas yang memburu dan cepat atau ngosngosan. Berbeda bila kita yang mampu mengatur nafas maka hal ini tidak akan terjadi dan stamina tetap terjaga. Berenang adalah simbol dari kekuatan dan ketahanan fisik yang prima yang harus dimiliki seorang Muslim.

\section{c. Memanah}

Memanah melatih kita dalam mengendalikan fokus, karena memanah identik dengan sasaran, keteguhan tantangan, kekuatan ]menarik gendewanya dan perkiraan angin. Rasulullah bersabda bahwa setiap anak muslim harus belajar atau melatih konsentrasi agar kita bias fokus pada sesuatu hal. Untuk bisa konsentrasi kita harus bisa ikhlas dan menyukai latihan, sehingga kita bisa mensinergikan antara pikiran dan perasaan. Pikiran fokus pada target, akan tercapi bila kita bisa mensinergikan antara kekuatan dan tubuh dengan pikiran dan perasaan.

Jika dikaitkan dengan kehidupan, hidup harus mempunyai sasaran yang jelas dan lakukan usaha untuk mencapainya dengan keteguhan tangan, kekuatan hati dan mampu menyesuaikan dengan perkembangan keadaan dunia ini. Sasaran merupakan acuan untuk melangkah dan fokus pada proses,bukan hasil akhir. 
Namun semua tidak hanya sebatas itu, Islam tidak membatasi jenis olahraga apa yang harus diajarkan di sekolah/madrasah, yang terpenting adalah peserta didik diberikan pembelajaran berbagai ketrampilan sebagai bekal hidup mereka. Hadits di atas, tertulis "Ajari anak-anak lelakimu" tidak berarti bahwa Alloh Swt membeda-bedakan antara anak perempuan dan laki-laki dalam mempelajari suatu ketrampilan.

Seperti fiman Allah dalam surah Al-Hujarrat ayat 13 yang berbunyi:

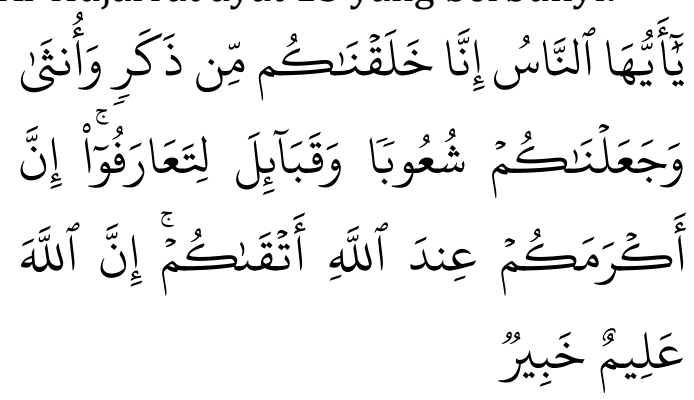

"Hai manusia, sesungguhnya Kami menciptakan kamu dari seorang laki-laki dan seorang perempuan dan menjadikan kamu berbangsa-bangsa dan bersuku-suku supaya kamu saling kenal-mengenal. Sesungguhnya orang yang paling mulia diantara kamu disisi Allah ialah orang yang paling takwa diantara kamu. Sesungguhnya Allah Maha Mengetahui lagi Maha Mengenal."

Dari penjelasan Surah Al Hujarrat ayat 13 dan Hadits Nabi di atas, bisa disimpulkan bahwa materi pembelajaran bisa disesuaikan dengan kebutuhan lembaga pendidikan yang bersangkutan. Di samping itu, minat dan bakat siswa juga harus menjadi pertimbangan. Misalnya, dalam pembelajaran ketrampilan berenang, sangat sulit sekali untuk diimplementasikan kepada peserta didik putri. Akan tetapi, jika madrasah bisa memfasilitasi olahraga ini untuk putri, misalnya ada khusus kolam renang putri, pakaian renang putri muslimah, dll., maka hal ini sangat memungkinkan untuk dilaksanakan. Demikian juga dengan ketrampilanketrampilan lainnya. Selain itu, ayat di atas juga membuktikan adanya gender equity (kesetaraan jender). Hal ini membuktikan bahwa perempuan juga mempunyai peran, tanggung jawab dan kesempatan yang sama dalam dunia pendidikan maupun bidang yang lainnya. Sungguh, Allah Maha Besar.

\section{Komponen Metode}

Merupakan komponen yang memiliki peran yang sangat penting, sebab berhubungan dengan implementasi kurikulum. Metode adalah upaya untuk mengimplementasikan rencana yang sudah disusun dalam kegiatan nyata agar tujuan yang telah disusun tercapai secara optimal. Ini berarti metode digunakan untuk merealisasikan strategi yang telah ditetapkan. Dengan demikian, bisa jadi satu strategi pembelajaran digunakan beberapa metode. Misalnya untuk melaksanakan strategi ekspositori bisa digunakan metode ceramah sekaligus metode tanya jawab atau bahkan diskusi dengan pemanfaatan sumber daya yang tersedia termasuk menggunakan media pembelajaran. Istilah lain juga yang memiliki kemiripan dengan strategi adalah pendekatan (approach). Sebenarnya pendekatan berbeda dengan strategi maupun metode. Pendekatan dapat diartikan sebagai titik tolak atau sudut pandang terhadap proses pembelajaran. Roy Killen mencatat ada dua pendekatan dalam 
pembelajaran, yaitu pendekatan yang berpusat pada guru (teacher centered approach) dan pendekatan yang berpusat pada siswa (student centered approach). Pendekatan yang berpusat pada guru menurunkan strategi pembelajaran langsung (direct nstruction), pembelajaran deduktif atau pembelajaran ekspositori. Sedangkan pendekatan pembelajaran yang berpusat pada siswa menurunkan strategi pembelajaran discovery dan inquiry serta strategi pembelajaran induktif. ${ }^{17}$ Dengan demikian, istilah pendekatan merujuk kepada pandangan tentang terjadinya suatu proses yang sifatnya masih sangat umum. Oleh karena itu, strategi dan metode pembelajaran yang digunakan dapat bersumber atau tergantung dari pendekatan tertentu.

Dalam surah Luqman 13-15 tergambar metode atau cara untuk mendidik anak. Ayat 13:

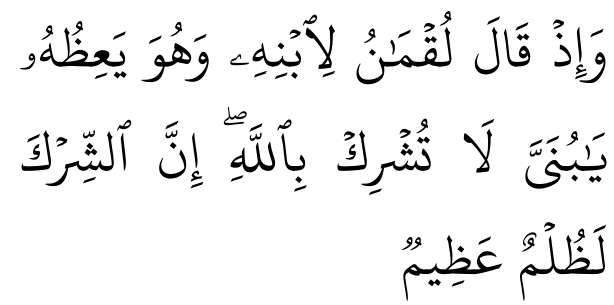

"Dan (ingatlah) ketika Luqman berkata kepada anaknya, di waktu ia memberi pelajaran kepadanya: "Hai anakku, janganlah kamu mempersekutukan Allah,

Sesungguhnya

mempersekutukan

adalah benar-benar kezaliman yang besar".
Adapun dalam hal ini masih banyak dipertanyakan tentang Luqman yang sebenarnya. Menurut M Quraish Syihab, orang Arab mengenal dua orang bernama Luqman. Pertama, Luqman Ibn 'ad. Tokoh ini terkenal dengan karakter wibawa, kepemimpinan, ilmu, kefasihan dan kepandaian. Dia seringkali dijadikan contoh dalam perumpamaan. Kedua, Luqman alHakim yang terkenal dengan katakata bijak perumpamaanperumpamaannya. Luqman inilah sepertinya yang dimaksud dalam ayat 13 ini.

Dalam kaitannya dengan dengan metode sebagai salah satu komponen kurikulum, para pendidik atau guru diharapkan bisa menggugah hati nurani peserta didik untuk selalu memberikan rasa hormat kepada guru sebagai orang tua mereka di madrasah sebagaimana yang mereka lakukan kepada orang tua kandung mereka. Maka sebgai pendidik, guru hendaknya menemukan metode yang tepat sekaligus tetap menjaga harga diri peserta didik untuk mau berbuat baik danhormat kepada orang tuanya. Telah di jelaskan selanjutnya pada Surah Al-Luqman ayat 15,

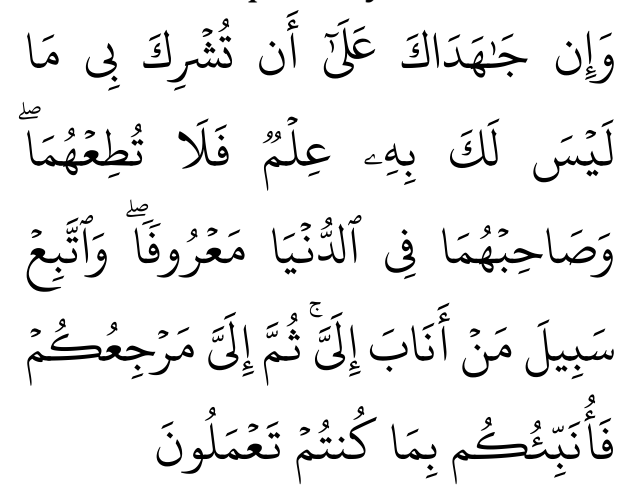

17 Roy Killen, Effective Teaching Strategies, Lessons from Research and Practice, (Australia: Social Science Press) 
"Dan jika keduanya memaksamu untuk mempersekutukan dengan Aku sesuatu yang tidak ada pengetahuanmu tentang itu, maka janganlah kamu mengikuti keduanya, dan pergaulilah keduanya di dunia dengan baik, dan ikutilah jalan orang yang kembali kepada-Ku, kemudian hanya kepada-Kulah kembalimu, maka Kuberitakan kepadamu apa yang telah kamu kerjakan."

Jika dalam ayat sebelumnya yang telah dibahas menyururh anak untuk berbakti kepada orang tua, maka dalam ayat ini ada sedikit pengecualian. Kita tidak selalu harus mematuhi mereka jika perintah orang tua tersebut menuju kepada kemusyrikan. Akan teteapi tidaklah boleh untuk kita memutus hubungan dengan orang tua kita. Kita harus tetap baik dalam urusan dunia bersama orang tua kita namunbukan untuk urusan akidah.

Demikian berdasarkan nasehat Luqman kepada anaknya, Allah telah memberikan petunjuk bagaimana mendidik anak dan dapat sebagai pedoman bagaimana kita membimbing peseta didik dengan sesuai yang telah Allah isyaratkan. Metode pembelajaran melalui interaksi yang harmonis antara pembelajar dan pendidik akan membawa dampak positif dalam penerimaan materi pelajaran. Diskusi kelompok sebagai salah satu metode pembelajaran mengadopsi baik teori barat maupun Islami karena didalamnya terjadi aktivitas interaksi antara pendidik dengan peserta didik, antara peserta didik dengan peserta didik lain, serta antara peserta didik dengan seluruh peserta didik.

\section{Komponen Evaluasi}

Evaluasi merupakan suatu komponen untuk melihat efektifitas dalam pencapaian tujuan Melalui evaluasi, dapat ditentukan nilai dan arti kurikulum sehingga dapat dijadikan bahan pertimbangan apakah suatu kurikulum perlu dipertahankan atau tidak, dan bagian-bagian mana yang harus disempurnakan. Dalam kurikulum, evaluasi dapat berfungsi untuk mengetahui sejauh mana pencapaian tujuan berdasarkan metode yang telah ditetapkan.

Dalam Al-Qur'an dijelaskan beberapa ayat tentang evaluasi dalam pembelajaran, seperti contoh dalam surat Al-Ankabut ayat 2-3 yang artinya sebagai berikut:

"Apakah manusia itu mengira bahwa mereka dibiarkan (saja) mengatakan: "Kami telah beriman", sedang mereka tidak diuji lagi?" (QS. Al-Ankabut : 2)

\section{Kemudian, \\ "Dan sesungguhnya kami telah menguji orang-orang yang sebelum mereka, maka sesungguhnya Allah mengetahui orang-orang yang benar dan sesungguhnya Dia mengetahui orang-orang yang dusta" (QS: Al-Ankabut : 3).}

Berdasarakan ayat diatas digambarkan salah satu evaluasi dalam Al-Qur'an yang harus bekerjalah kamu, maka Allah dan Rasulnya serta orang-orang mukmin akan melihat pekerjaanmu, maksudnya ialah segala perbuatan dan pekerjaan kita yang baik maupun yang buruk tidak terlepas dengan pengawasan Allah, segala perbuatan akan dikembalikan dan di pertanyakan dihadapan Allah baik itu yang tidak tampak, maupun yang 
nyata. lalu di beritakanlah apa yang kamu kerjakan di dunia dan di perlihatkan segala pekerjaanmu di akhirat kelak.

Evaluasi sebagai alat untuk melihat keberhasilan pencapaian tujuan dapat dikelompokkan kedalam dua jenis, yaitu tes dan nontes. ${ }^{18}$ Evaluasi tes merupakan evaluasi yang terstruktur dan sistematis sedangkan evaluasi nontes biasanya digunakan sebagai kritikan terhadap sebuah kelemahan. Teknik ini biasanya melalui wawancara atau observasi.

Selanjutya Oemar Hamalik menambahkan komponen Organisasi dalam kurikulum, yaitu lembaga penyelenggara pendidikan itu sendiri juga sangat mempengaruhi tercapainya tujuan pendidikan itu sendiri. ${ }^{19}$

\section{KESIMPULAN}

Kurikulum Pendidikan dalam Kajian Al-Qur'an \& Hadits, dapat kita gali atau perdalami dengan berbagai aspek. Salah satunya ialah aspek ontology dan epistemolgi. Dalam aspek ontologi telah dibahas secara detail pengertian kurikulum itu sendiri dari mulai etimologi yang membahas tentang pengertian secara bahasa atau lughawi sampai secara terminology yang membahas dengan nilai-nilai atau istilah sehingga lebih mudah diafahami.

Pada aspek epistemologi kita mengetahui bagaimana Al-Qur'an telah mengajarkan kita caracara/metode mengajar kepada peserta didik kita. Komponen kurikulum antara lain:

Pertama, Komponen tujuan kurikulum. Pada hakekatnya, tujuan

\footnotetext{
18 M.Scriven, The Methodology of Evaluation, dalam R. W. Tyler, R. M. Gagné, \& M. Scriven (Eds.), Perspectives of curriculum evaluation, (Chicago: IL: Rand McNally, 1967), 39-83
}

kurikulum ada tiga macam, yaitu Tujuan Nasional, Tujuan Institusional dan Tujuan Kurikuler. Tujuan Nasional tentu saja tujuan yang tercantum dalam UndangUndang Sisdiknas. Tujuan Institusional sesuai dengan tujuan lembaga pendidikan sebagai penyelenggara pendidikan. Sedangkan Tujuan Kurikuler adalah tujuan yang akan dicapai pada setiap bidang studi yang diajarkan.

Kedua, komponen materi. Secara umum, materi kurikulum dalam pembelajaran sudah tercantum dalam Kompetensi Inti dan Kompetensi Dasar yang tercantum dalam Permendiknas Nomor 57, 58, 59 tahun 2014. Akan tetapi, jika kita mau melihat di dalam Al-Qur'an hampir semua ilmu yang ada di dunia sudah tercantum di dalamnya

Ketiga, komponen metode. Merupakan komponen yang memiliki peran yang sangat penting, sebab berhubungan dengan implementasi kurikulum. Metode adalah upaya untuk mengimplementasikan rencana yang sudah disusun dalam kegiatan nyata agar tujuan yang telah disusun tercapai.

Keempat, komponen evaluasi. Evaluasi merupakan suatu komponen untuk melihat efektifitas dalam pencapaian tujuan Melalui evaluasi, dapat ditentukan nilai dan arti kurikulum sehingga dapat dijadikan bahan pertimbangan apakah suatu kurikulum perlu dipertahankan atau tidak, dan bagian-bagian mana yang harus disempurnakan. Dalam kurikulum, evaluasi dapat berfungsi untuk mengetahui sejauh mana pencapaian tujuan berdasarkan metode yang telah ditetapkan.

\footnotetext{
19 Oemar Hamalik, Manajemen Pengembangan Kurikulum, (Bandung: PT Remaja Rosdakarya, 2008), 95
} 


\section{DAFTAR PUSTAKA}

Gunawan, Heri, Kurikulum dan Pembelajaran Pendidikan Agama Islam, (Bandung: Alfabeta, 2012)

Hamalik, Oemar, Manajemen Pengembangan Kurikulum, (Bandung: PT Remaja Rosdakarya, 2008)

Hasan, S. Hamid, Informasi Kurikulum 2013, Jakarta: Sasiti Nugrahaningsih, 2013)

Hornby, A.S., Oxford Advanced Learner's Dictionary of Current English, (USA: Oxford University Press, 1995)

https://play.google.com/store/apps/ details?id=com.girfa.apps.book. muslim

Killen, Roy, Effective Teaching Strategies, Lessons from Research and Practice, (Australia: Social Science Press) Mursalim dan Hatta, Inovasi Pengembangan Kurikulum PAI di Sekolah Menengah Pertama Raudatut Tholabah Berbasis Pesantren, (Jember: Fakultas
Tarbiyah dan Ilmu Keguruan: IAIN Jember, 2020)

Nasution, Kurikulum \& Pengajaran, (Jakarta: PT Bumi Aksara, 2012)

Sanjaya, Wina, Pembelajaran dalam Implementasi Kurikulum Berbasis Kompetensi, (Jakarta: Kencana Prenada Media Group, 2006)

Scriven, M., The Methodology of Evaluation, dalam R. W. Tyler, R. M. Gagné, \& M. Scriven (Eds.), Perspectives of curriculum evaluation, (Chicago: IL: Rand McNally, 1967)

Syihab, M Quraish, Tafsir Al-Mishbah : Pesan, Kesan dan Keserasisan AlQur'an (Volume 11), (Jakarta: Lentera Hati, 2002)

Umairah, Abdurrahman, Metode AlQur'an Dalam Pendidikan, Alih Bahasa: Abdul Hadi Basulthanah, (Surabaya: Mutiara Ilmu, 2000) 